VOLUME 6 No. 2

DEC 2009

ISSN 1675-7017
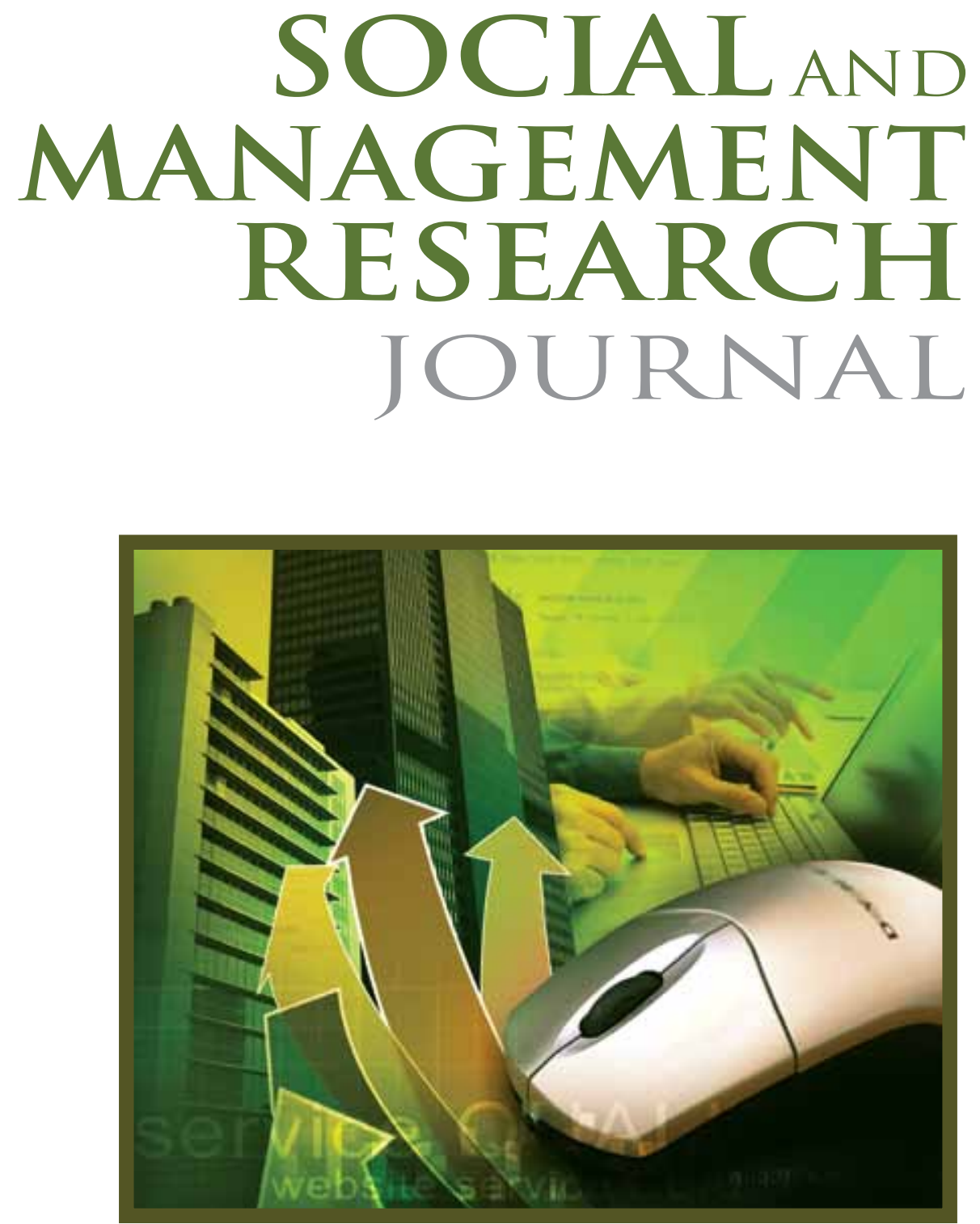
SOCIAL AND MANAGEMENT RESEARCH JOURNAL

\author{
Chief Editor \\ Prof. Dr. Rashidah Abdul Rahman, \\ Universiti Teknologi MARA, Malaysia

\section{Managing Editor} \\ Assoc. Prof. Dr. Loo Ern Chen, \\ Universiti Teknologi MARA, Malaysia
}

\title{
Editorial Advisory and Review Board
}

Prof. Dr. Normah Omar, Universiti Teknologi MARA, Malaysia Assistant Prof. Alexander N. Kostyuk, Ukrainian Academy of Banking of National Bank of Ukraine, Sumy, Ukraine

Prof. Dr. Faridah Hassan, Universiti Teknologi MARA, Malaysia Prof. Dr. Sardar M.N. Islam, Victoria University, Melbourne, Australia Assoc. Prof. Dr. Razidah Ismail, Universiti Teknologi MARA, Malaysia

Assoc. Prof. Dr. Nor'azam Matstuki, Universiti Teknologi MARA, Malaysia

Assoc. Prof. Dr. Kiranjit Kaur, Universiti Teknologi MARA, Malaysia Assoc. Prof. Dr. Sabarinah Sheikh Ahmad, Universiti Teknologi MARA, Malaysia Assoc. Prof. Dr. Nor Aziah Alias, Universiti Teknologi MARA, Malaysia Assoc. Prof. Dr. Maznah Wan Omar, Universiti Teknologi MARA, Malaysia Assoc. Prof. Dr. Lionel Wee, National University of Singapore, Singapore Assoc. Prof. Dr. Binh Tram-Nam, The University of New South Wales, Sydney, Australia

Dr. Kalsom Salleh, Universiti Teknologi MARA, Malaysia Dr. Azmi Abdul Hamid, Universiti Teknologi MARA, Malaysia Dr. Ria Nelly Sari, Universitas Riau, Riau, Indonesia

Dr. Agus Harjitok, Universitas Islam Indonesia, Jogjakarta, Indonesia

Dr. Rashid Ameer, Universiti Teknologi MARA, Malaysia

Dr. Radiah Othman, Universiti Teknologi MARA, Malaysia

Dr. Megawati Omar, Universiti Teknologi MARA, Malaysia

Dr. Azizah Abdullah, Universiti Teknologi MARA, Malaysia

Siti Noor Hayati Mohamed Zawawi, Universiti Teknologi MARA, Malaysia

Copyright (C) 2009 by Research Management Institute (RMI), Universiti Teknologi MARA, 40450 Shah Alam, Selangor, Malaysia.

All rights reserved. No part of this publication may be reproduced, stored in a retrieval system or transmitted in any form or by any means; electronics, mechanical, photocopying, recording or otherwise; without prior permission in writing from the Publisher.

Social and Management Research Journal is jointly published by Research Management Institute (RMI) and University Publication Centre (UPENA), Universiti Teknologi MARA, 40450 Shah Alam, Selangor, Malaysia.

The views and opinion expressed therein are those of the individual authors and the publication of these statements in the Scientific Research Journal do not imply endorsement by the publisher or the editorial staff. Copyright is vested in Universiti Teknologi MARA. Written permission is required to reproduce any part of this publication. 


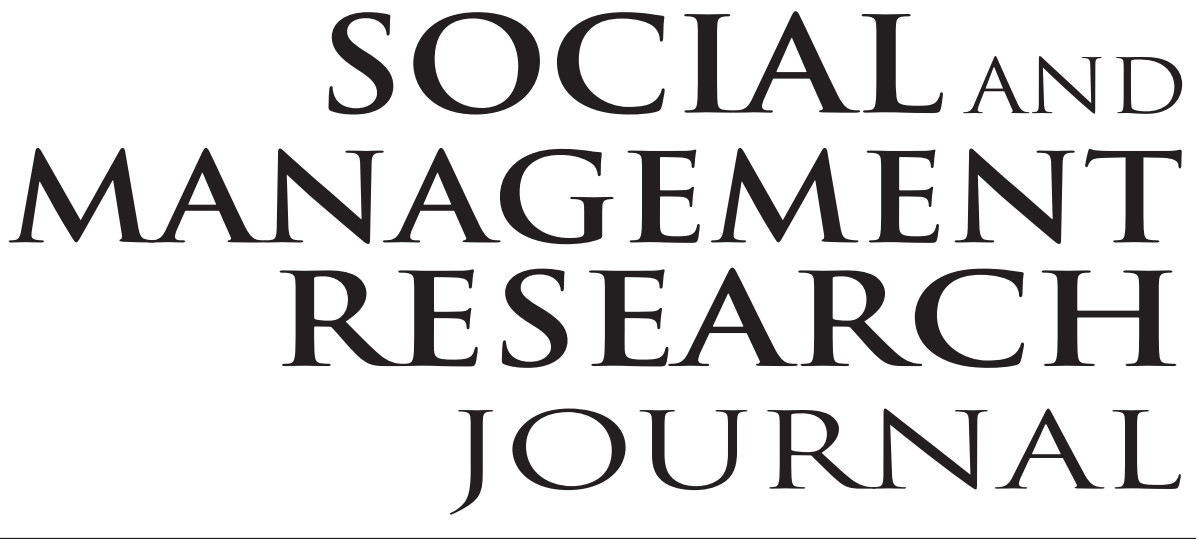

Vol. 6 No. 2

December 2009

ISSN 1675-7017

1. Does Organizational Ethical Climate Influence Auditors in

Perceiving Ethical Problems and Forming Ethical Judgments?

Maheran Zakaria

Hasnah Haron

Ishak Ismail

2. Business Students at University: Are They Trained to Cheat?

Faizah Mohd Khalid

Siti Jeslyn Hasan

3. Gender and Belief Factors on Attitude Towards Social and

Environmental Accounting (SEA)

Salina Abdullah

Loo Ern Chen

4. Measuring Website Service Quality for Malaysian Companies

Voon Boo Ho

Karen Kueh

Mohd Zawawi Mohd Zafian

5. Examination of the Empirical Dimensionality of Job

Performance Construct

Johanim Johari

Khulida Kirana Yahya

Abdullah Omar 


\title{
Measuring Website Service Quality for Malaysian Companies
}

\author{
Voon Boo Ho ${ }^{1,3}$, Karen Kueh² and Mohd Zawawi Mohd Zafian \\ ${ }^{1}$ Faculty of Business Management, Universiti Teknologi MARA \\ Cawangan Sarawak, Jalan Meranek, 94300 Kota Samarahan, Sarawak \\ ${ }^{2}$ Swinburne University of Technology, Sarawak Campus \\ ${ }^{3}$ Email: bhvoon@sarawak.uitm.edu.my
}

\begin{abstract}
A customer-perceived quality service has been widely used towards enhancing the customers' satisfaction and loyalty. The same situation is also applicable for the online services; in an increased use of websites as a channel for information presentation and provision of other services. Hence, the website service quality perceptions of users need to be understood so as to be managed more effectively. The key dimension of this study is to identify the website service quality through the qualitative and quantitative approaches. The website quality theories, focus groups and survey results generate numerous dimensions and items for the understanding and measuring the website service quality of various public-listed companies in Malaysia, particularly from the users' viewpoint. The laboratory-based method obtains data from the external users' websites whereas mail surveys aims to gather the views from the organizations' website. These two approaches use to obtain the perceptual data for further quantitative analysis. Based on the Reliability and Factor Analysis as well as Structural Equation Modeling, there are six valid and reliable dimensions of website service quality identified, namely: Assurance, Tangibles, Content Quality, Technical Quality, Organisation Information, and Address. The implications and future research directions will be also discussed in the following sections of this study.
\end{abstract}

Keywords: Website service quality, users, measurement model, Malaysia

ISSN 1675-7017

(C) 2009 Universiti Teknologi MARA (UiTM), Malaysia. 


\section{Introduction}

The invention of Internet, or also known as Net, has been acting as a world wide collection of networks that links millions of businesses, private and government agencies, educational institutions and individuals; through which performance can be rapidly and effectively carried out. This service provides accessibilities to various types of resources such as goods, services, facts and information to its consumers by 24 hours a day. The rapid development in information, communication and technology (ICT) has contributed to an increased demand in internet services and the use of websites as an effective channel for online communication. Shelly, Cashman and Vermaat (2005) in their study assert that there are nine categories of Web sites available on the Net. Internet marketing gains recognition by the presentation of quality and beneficial information on its portal (Yang et al., 2004). As for this reason, having advantageous websites or portals are undoubtedly significant both to the organizations or individuals. Despite the fact that many researchers and practitioners have emphasized on the measurement and management of a quality website (e.g. Webb and Webb, 2004; Aladwani and Palvia, 2002; Yoo and Donthu, 2001), only limited attention has been given to this perspective. Thus, it is believed that the users' perspective on the market-oriented approach is important and necessary to achieve a success (e.g. Voon, 2006; Sorensen, 2009). A ground of understanding is that a quality website service delivery has higher opportunity to enhance the users' satisfaction and loyalty. The ultimate purpose of this paper is to identify the dimensions of user-perceived website on the quality service.

\section{Literature Review}

At present, the age of electronic or online commerce serves as a platform to the organizations to provide the public with their corporate profile, products and services as well as eventually to generate online sales. Websites is therefore served both informational as well as marketing purposes (Palmer and Griffith, 1998). Accordingly, the website design and features used are vital in influencing the users' attitudes and perceptions towards the organizational websites as beneficial and advantageous as well as in turn affects their behavioral intentions to repurchase (Hausman and Siekpe, 2009). A study conducted on the website design has also affirmed that the layout of an organizational website play 
a significant role in affecting the satisfaction to online shoppers (Szymanski and Hise, 2000). As for this reason, the needs and interest of users must be taken into consideration while designing for a corporate website (Madu and Madu, 2002). Cox and Dale (2001) compare the quality service on the web with the traditional channel as such face-to-face interactions with customers and acknowledge that there are applicable for the online service, namely: accessibility, communication, reliability, security, appearance, functionality and integrity. Aladwani and Palvia (2002) assert that a quality web is a multi-dimensional concept that has yet to be properly defined. They present a definition of web quality from the users' perceptions based on how well the website meets the users' needs. There are four dimensions of quality web are identified. The first dimension refers to the technical adequacy specifically the features and performance of the website such as search facilities, customization, speed of loading, security and interactivity. The second dimension concerns about the appearance and visual appeal of the website, such as the appropriate use of fonts, colors, graphics and length of the page. The third dimension focuses on the quality content; including the completeness and accuracy of information whereas the last dimension centers at a specific content related to products, customer support and privacy.

Huizingh (2000) differentiates between the content and design of a website; content and the features on the website enable to communicate information, online transactions and enhance the online exposure through infotainment animation such as video clips and games. On the other hand, the design of a website includes its navigation structure and search function. He also asserts that websites are varied from industries particularly in terms of content and design; websites with more pages are seen as more complex for and it differs from one industrial expectation to another.

Santos (2003) presents another framework for e-service quality based on an incubate and active dimensions. The incubate dimension is mainly concerned with the development of a website; including prior to its launching. Elements of content, appearance, user friendly linkage, structure and layout are significantly important as a way to attract users to visit and stay longer. In contrast, the active dimension lies on an ongoing activity of the website and encourage customers to continue dealing with the company through its efficiency, reliability, security and support

In order to measure the level of customers' satisfaction, Muylle et al. (2004) focus on the three identified dimensions, namely, information, connection and layout. The elements of information consist of information 
relevancy, accuracy, comprehensibility and comprehensiveness, while the connection concerns with the organization of its content structure, user friendly, entry guidance, hyperlink connotation as well as the rapidity. Finally, the layout of the website includes all the visual elements such as text, graphic, animation and three-dimensional typography. Although various frameworks of quality website have been proposed, none have specifically focus on how excellent a website could be in providing services to its online customers (visitors or users). However, it is also worth to acknowledge that since a website serves a variety of customers who may use it for informational as well as transactional purposes, thus, it is essential to identify the elements of service and develop a tool to measure its effectiveness.

\section{Methodology}

This paper aims at exploring the empirical findings on user-perceived quality website service from the viewpoint of Malaysian users. The questionnaire surveys (laboratory-based and mail survey) were disseminated to the respondents mainly to identify the dimensions of quality website service. Relevant literature review (e.g. Aladwani and Palvia, 2002) and quality service (e.g. Parasuraman et al., 1988; Parasuraman et al., 2005) research as well as the findings based on four focus groups were used to generate responses and ultimately to measure the intended quality website service. Forty-three statements were used to quantify the user-perceived quality website service (the phrase of development). The questionnaire was carefully designed and the items were measured by using the 7 -points Likert scale $(1=$ Strongly Disagree and $7=$ Strongly Agree). However, only single-item was assessed for the overall measurement of quality website. There were four items were used to identify the user satisfaction namely 'I am satisfied with the website', 'The website fulfill my expectations', 'I am not disappointed with the website' and 'My experience with the website is good'. Furthermore, the user loyalty was measured by using two items; the intention of users and recommend the website to others.

A method of pilot-test questionnaires was administered for the respondents within the computer laboratory settings as this approach is believed to generate more accurate, comprehensive and reliable data with a constant result. Each of the 200 respondents (external users) was invited to assess 30 corporate websites at random (from different industrial 
sectors) based on the procedures provided by the researchers. The respondents were initially briefed on the various web-related technical terms and demonstrated on how to make a website visit which took approximately 20 minutes by the Information System experts prior to the answering session. The process of data collection has yielded 5939 usable responses. In addition, a mail survey was conducted with one hundred and one employees from selected public-listed companies in Malaysia; by having assessed to their own company's website with regards to the refined questionnaire (35 items only).

\section{Findings and Discussions}

The demographic data of two hundred respondents for the laboratorybased survey are as follows: within the age of 21 to 30 years old, $61 \%$ of them are female and the average times of visiting websites per week is 11. The finding also indicates that $43.2 \%$ of them are diploma holders whereas the $33.2 \%$ of them are with degree. There are 599 company websites $(\mathrm{Na}=5939)$ been assessed according to its respective sectors as such Industrial $(26.8 \%)$, Trading/Services $(26.6 \%)$, Consumer Products $(13.5 \%)$, Properties $(13.1 \%)$ and others $(20.0 \%)$.

On the other hand, there were one hundred and one employees participated in the mail survey $(\mathrm{Nb}=101)$. Interestingly, most of them were female ( $56 \%$ ), approximately of $44 \%$ of them were with ranged of 21-30 years old and bachelor degree holders. The websites were assessed from various industries namely: Industrial (20.4\%), Trading/Services (4.9 \%), Consumer Products (25.2\%), Properties (22.3\%) and others $(27.2 \%)$.

An exploratory factor analysis (EFA) was effectively used to screen the results (using principal component analysis with varimax rotation, on the development sample $\mathrm{Na}=5939$ ) and to measure the quality website service based on the seven identified dimensions (Table 1, indicating a series of 35 items). The factors (each factor has Eigenvalue more than 1) explained about $65 \%$ of the total variance. The Kaiser-Meyer-Olkin Measure stood at 0.975 indicating good sampling adequacy.

A Confirmatory factor analysis was carried out by using the AMOS software. The model of 7-dimension is based on the exploratory factor analysis which has been tested earlier, however, was not demonstrated as the goodness-of-fit index values were below the desired values. This situation is seen as not compatible with the measurement in most of the 
Table 1: Dimensions and Items on Quality Website Service from the EFA

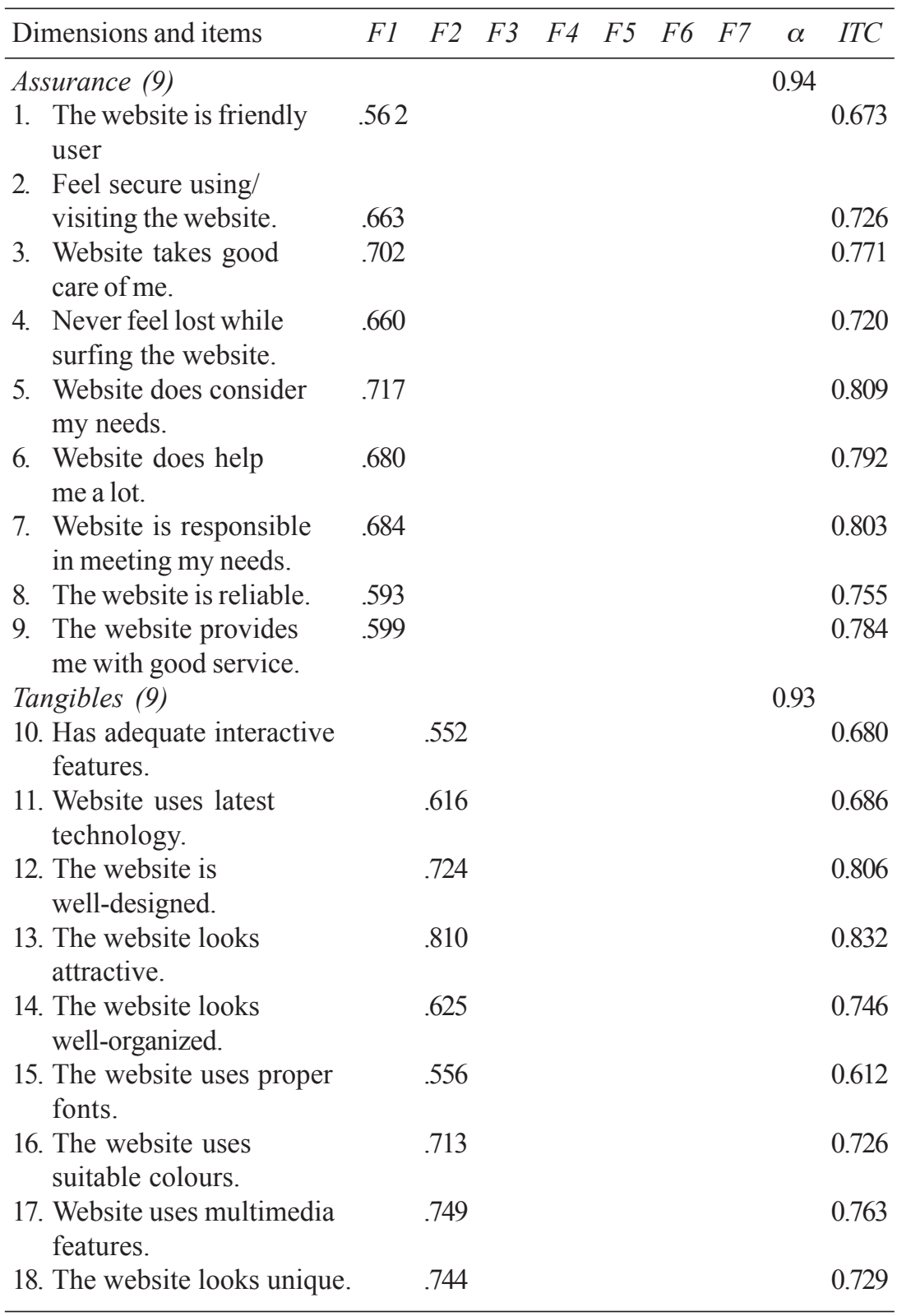


Table 1 (continued)

\begin{tabular}{|c|c|c|c|c|c|c|c|c|c|}
\hline Dimensions and items & $F 1$ & $F 2$ & $F 3$ & F4 & F5 & F6 & $F 7$ & $\alpha$ & ITC \\
\hline Quality of Content (6) & & & & & & & & 0.87 & \\
\hline $\begin{array}{l}\text { 19. Content of the website is } \\
\text { useful. }\end{array}$ & & & .550 & & & & & & 0.726 \\
\hline $\begin{array}{l}\text { 20. Content of website is } \\
\text { comprehensive. }\end{array}$ & & & .585 & & & & & & 0.716 \\
\hline $\begin{array}{l}\text { 21. Content of website is } \\
\text { up-to-date. }\end{array}$ & & & .573 & & & & & & 0.590 \\
\hline $\begin{array}{l}\text { 22. Content of the website } \\
\text { is concise. }\end{array}$ & & & .613 & & & & & & 0.754 \\
\hline $\begin{array}{l}\text { 23. Content of the website } \\
\text { is accurate. }\end{array}$ & & & .592 & & & & & & 0.707 \\
\hline $\begin{array}{l}\text { 24. The content suits into } \\
\text { cultural background. }\end{array}$ & & & .520 & & & & & & 0.533 \\
\hline Quality of Technicality (4) & & & & & & & & 0.83 & \\
\hline $\begin{array}{l}\text { 25. Website is easy to } \\
\text { surf through. }\end{array}$ & & & & .687 & & & & & 0.675 \\
\hline 26. Website is well functioning & & & & .650 & & & & & 0.673 \\
\hline 27. Rapid loading of web page & & & & 764 & & & & & 0.617 \\
\hline 28. Website is easily accessed & & & & .705 & & & & & 0.719 \\
\hline Organization of Information & & & & & & & & 0.79 & \\
\hline $\begin{array}{l}\text { 29. Contact information of } \\
\text { company. }\end{array}$ & & & & & .748 & & & & 0.633 \\
\hline $\begin{array}{l}\text { 30. General information of } \\
\text { company. }\end{array}$ & & & & & .757 & & & & 0.709 \\
\hline $\begin{array}{l}\text { 31. Details of product and/ } \\
\text { or services. }\end{array}$ & & & & & .606 & & & & 0.540 \\
\hline Information Service (2) & & & & & & & & 0.79 & \\
\hline $\begin{array}{l}\text { 32. Information on customers' } \\
\text { policies. }\end{array}$ & & & & & & .819 & & & 0.651 \\
\hline $\begin{array}{l}\text { 33. Information on customer } \\
\text { service. }\end{array}$ & & & & & & .780 & & & 0.651 \\
\hline Address (2) & & & & & & & & 0.77 & \\
\hline 34. Memorable website addres & & & & & & & .783 & & 0.632 \\
\hline $\begin{array}{l}\text { 35. Website address reflects } \\
\text { on the company's name }\end{array}$ & & & & & & & .771 & & 0.632 \\
\hline Eigen values and Variance & 18.8 & 2.2 & 1.7 & 1.6 & 1.4 & 1.1 & 1.1 & & \\
\hline $\begin{array}{l}\text { Explained (Total variance } \\
\text { explained: } 64.7 \% \text { ) }\end{array}$ & 43.6 & 5.2 & 3.9 & 3.6 & 3.3 & 2.6 & 2.5 & & \\
\hline
\end{tabular}


marketing literatures (i.e., 0.90). Besides the model of 7-dimension, the model of 6-dimension (Figure 1, indicating the original item numbers) was applied in the Information Service. The results have signified the improvement as it fits into the statistical model used (e.g. NFI $=0.91$; IFI $=0.91 ; \mathrm{TLI}=0.90 ; \mathrm{CFI}=0.91 ; \mathrm{RMSEA}=0.064)$. Taken as a whole, all the factors are significant and have exceeded 0.5 (0.582 to 0.865$)$ which is indicating a valid convergence.

The findings signify that items used in determining quality website service are satisfactory and consistent. Seeing that the result for the Cronbach's Alpha $(\alpha)$ which has reached at the mandatory level of 0.70 (Nunnally and Bernstein, 1994). The corrected item-total correlations (ITC) for items within the dimensions also portray good internal consistency which is higher than 0.50 . The result for an internal consistency which has split the sampling into three categories $(\mathrm{N} 1=$

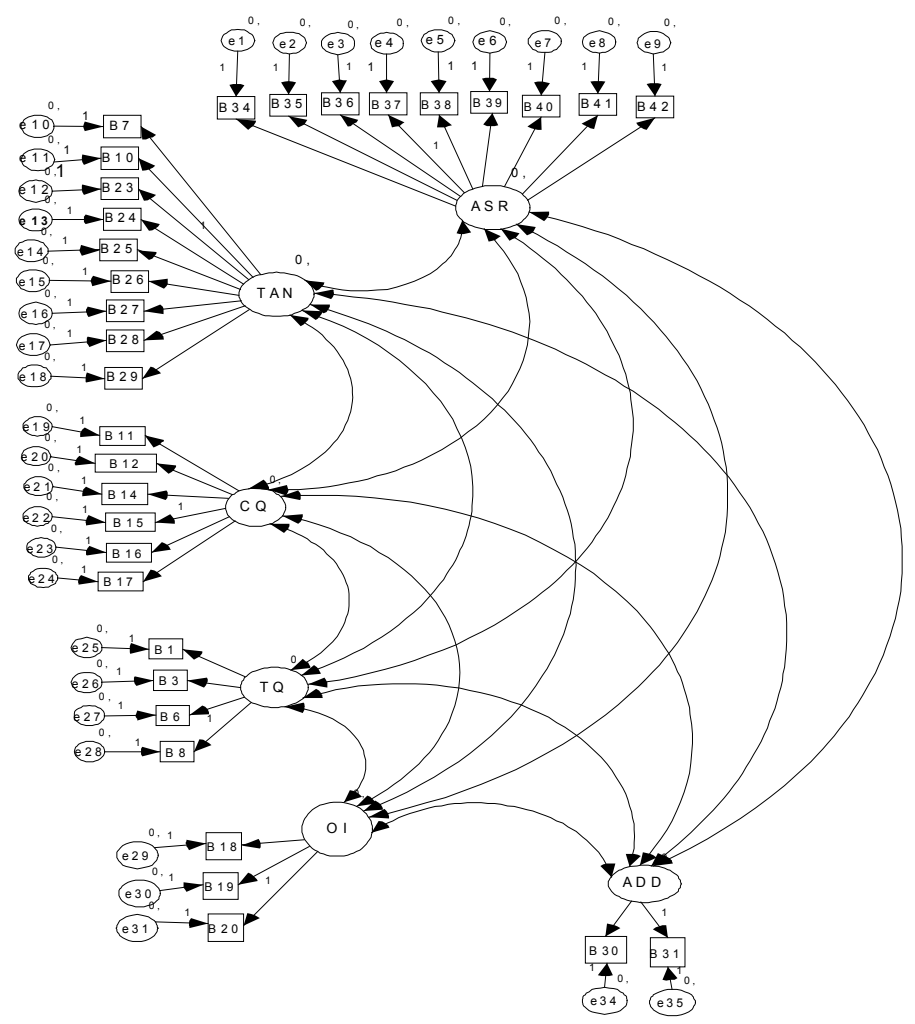

Figure 1: The Measurement for Confirmatory Factory Analysis Model 
$2364, \mathrm{~N} 2=2279$ and N3 $=1296$ ) also indicated an element of reliability for the overall measurement.

A consistency of the respondents $(\mathrm{Nb}=101)$ also specify satisfactory results. On the other hand, the results of correlation analysis indicate that the 6-dimensions are satisfactorily correlated. Besides, the dimensions are moderately or strongly correlated with the user-perceived Overall Quality evidenced as a valid convergent to the measurement. Thus, based on the study, it is found that the correlations between the satisfaction of users and loyalty of users are significantly interrelated.

\section{Conclusions and Implications}

This Malaysian-based survey research indicates that the user-perceived quality website service has been constructed based on a multi-dimensional approach explicitly the Assurance, Tangibles, Quality of Technicality, Quality of Content, Organization of Information and Address of the website. The above-mentioned elements are closely related to the overall user-perceived quality websites. Accordingly, it is believed that the userperceived quality website service exerts a positive influence on the users' satisfaction and loyalty (i.e., behavioural intentions).

The research findings suggest that in order to enhance an online service, the measurement and management of quality website should be focused on the user's point of view, interests and expectations. For that reason, the perceptions and feedbacks from the users or visitors are significantly essential for the development as well as further improvement of the corporate websites. Besides, the evaluation of a quality website service should also focus on the various orientations of service. The service-driven websites are believed to be crucial in attracting the users' interests to visit, recommend the website to others and ultimately to build a favorable corporate reputation.

Despite the fact that this newly developed measurement serve as a crucial diagnostic tool to signify the objective of performance and to monitor the purpose of a quality website service, this type of measurement still requires more improvement and more validation research. It is also recommended that the future research could expand scope of study into different types of websites in order to validate the measurement and confirmatory factor analysis. As for the purpose of this research, various models have been applied as a way to produce an undisputable judgment as well as conclusion. Besides, a longitudinal research should be 
undertaken for further investigation on the causal effects of the userperceived quality website service in determining their satisfaction and loyalty. A full structural equation model should also be applied in examining the causal relationships and numerous test-retest checks by using the cross-cultural data.

\section{References}

Adam, S., Vocino, A. and Bednall, D. (2009). The world wide web in modern marketing's contribution to organisational performance. Marketing Intelligence \& Planning, 27(1), 7-24.

Aladwani, A. and Palvia, P. (2002). Developing and validating an instrument for measuring user-perceived web quality. Information and Management, 39, 467-476.

Cox, J. and Dale, B.G. (2001). Service quality and e-commerce: An exploratory analysis. Managing Service Quality, 11(2), pp.121-131.

Hausman, A. and Siekpe, J. (2009). The effect of web interface features on consumer online purchase intentions. Journal of Business Research, 62, 5-13.

Huizingh, E. (2000). The content and design of web sites: an empirical study. Information \& Management, 37, 123-134.

Madu, C. and Madu, A. (2002). Dimensions of e-quality. International Journal of Quality \& Reliability Management, 19(3), 246-258.

Muylle, S., Moenaert, R. and Despontin, M. 2003. The conceptualization and empirical validation of web site user satisfaction. Information and Management, 41, 543-560.

Nunnally, J. and Bernstein, I. (1994). Psychometric Theory. ( $3^{\text {rd }}$ ed) New York: McGraw-Hill, Inc.

Palmer, J. and Griffith, D. (2008). Information intensity: A paradigm for understanding web site design. Journal of Marketing Theory and Practice, 38-42. 
Parasuraman, A., Zeithaml, V. and Berry, L. (1988). SERVQUAL: A multiple-item scale for measuring consumer perceptions of service quality. Journal of Retailing, 64(1), 12-40.

Parasuraman, A., Zeithaml, V. A. and Malhotra, A. (2005). E-S-Qual: A multiple-item scale for assessing electronic service quality. Journal of Service Research, 7(3), 213-233.

Santos, J. (2003). E-service quality: a model of virtual service quality dimensions. Managing Service Quality, 13(3), 233-246.

Shelly, G., Cashman, T. J. and Vermat, M. E. (2005). Discovering computers 2006: A gateway to information, Web Enchanted Complete. Boston: Course Technology:

Sørensen, H. (2009). Why competitors matter for market orientation. European Journal of Marketing, 43(5/6), 735-761.

Syzmanski, D. and Hise, R. (2000). E-Satisfaction: An initial examination, Journal of Retailing, 76(3), 309-322.

Voon, B. (2006). Linking a service-driven market orientation to service quality. Managing Service Quality, 16(6), 595-619.

Webb, H. and Webb, L. (2004). SiteQual: An integrated measure of web site quality. The Journal of Enterprise Information Management, 17(6), 430-440.

Yang, Z., Cai, S., Zhou, Z. and Zhou, N. (2004). Development and validation of an instrument to measure user perceived service quality of information presenting Web portals. Information and Management, 42, 575-589.

Yoo, B. and Donthu, N. (2001). Developing a scale to measure the perceived quality of an internet shopping site (SITEQUAL). Quarterly Journal of Electronic Commerce, 2(1), 31-45. 